\title{
Istihsan Sebagai Metode Istimbath Hukum Imam Hanafi Dan Relevansinya Dalam Pengembangan Ekonomi Syariah
}

\author{
Arif Nur'aini', Muttaqin Muhammad Ngizzul ${ }^{2}$ \\ ${ }^{I}$ STAI Diponegoro Tulungagung, ${ }^{2}$ Program Pascasarjana IAIN Tulungagung \\ ${ }^{1}$ jeniuz.nirwasita19@gmail.com, ${ }^{2}$ muttaqinizzul19@gmail.com
}

\begin{abstract}
The problems and competition between conventional economics and Islamic economics need to be answered with a relevant new ijtihad. One method of ijtihad that was initiated is istihsan by Imam Hanafi, where istihsan provides a legal breakthrough by transferring to a stronger and maslahah in law. The ijtihad is considered very important in order to provide breakthroughs and development of the Islamic economy. Where in each entity of thought certainly has its own methodology and thinking framework. Likewise with a theoretical framework regarding islamic economics. One framework of Islamic economic methodology that is different from conventional economic methodologies is the framework of thinking that starts from ushul fiqh (istimbath legal of method). Usul fiqh has a very strong role in contributing to the emergence of Islamic economics. Istihsan as one of the istimbath methods of Islamic law (ushul fiqh), of course that must be given more portions in order to further develop the Islamic economy. This research uses library research with in-depth analysis. The findings in this study are indicate that the development of Islamic economics starts from the basics in the form of a new ijtihad model using the istihsan method. Where the development of Islamic economics through this istihsan through breakthroughs in justice, maslahah, and honesty in every economic behavior
\end{abstract}

Keywords: Islamic economics, Usul fiqh, istimbath law of method, Istihsan.

\begin{abstract}
Abstrak
Problematika dan persaingan antara ekonomi konvensional dan ekonomi syariah perlu dijawab dengan sebuah model ijtihad baru yang relevan. Salah satu metode ijtihad yang digagas oleh Imam Hanafi adalah istihsan, dimana istihsan memberikan terobosan hukum dengan memindahkan kepada hukum yang lebih kuat dan maslahah. Model ijtihad ini dirasa sangat penting dalam rangka memberikan terobosan dan pengembangan terhadap ekonomi syariah. Dimana dalam setiap entitas pemikiran tentu mempunyai metodologi dan kerangka berfikir tersendiri. Demikian juga dengan kerangka teoritik mengenai ekonomi syariah. Salah satu kerangka metodologi ekonomi syariah yang berbeda dengan metodologi ekonomi konvensional ialah kerangka berifikir yang berangkat dari ushul fiqh (metode istimbath hukum). Ushul fiqh mempunyai peran yang sangat kuat dalam memberikan sumbangan atas tercetusnya ilmu ekonomi syariah. Istihsan sebagai salah satu metode istimbath hukum islam (ushul fiqh), tentu harus diberikan porsi lebih dalam rangka mengembangkan lebih lanjut terhadap ekonomi syariah. Penelitian ini menggunakan studi kepustakaan (library research) dengan analisis secara mendalam. Temuan dalam penelitian ini menunjukkan bahwa pengembangan ekonomi syariah dimulai dari hal dasar berupa model ijtihad baru menggunakan metode istihsan. Dimana
\end{abstract}


pengembangan ekonomi syariah melalui istihsan ini melalui terobosan keadilan, maslahah, dan kejujuran dalam setiap perilaku ekonomi

Kata Kunci: Ekonomi syariah, Ushul fiqh, Metode istimbath hukum, Istihsan

\section{Pendahuluan}

Ekonomi syariah dalam perkembangan dunia hari ini menjadi pesat dan menjadi pusat kajian oleh kalangan akademisi. Kajian terhadap ekonomi syariah mulai dirintis tatkala munculnya gagasan tentang pendirian bank Islam dalam sidang Organisasi Konferensi Islam (OKI) di Karachi pada bulan Februari 1973. Dalam pandangan M.A. Mannan, para ulama' telah membahas ekonomi sejak abad pertama yang diajarkan oleh Nabi Muhammad SAW. ${ }^{1}$ Pada perkembangannya, ekonomi syariah pada periode ini mengalami perkembangan yang sangat signifikan, baik dalam kancah nasional Indonesia maupun pada kancah Internasional, cakupannya meliputi; asuransi syariah, perbankan syariah, pasar modal syariah, obligasi syariah, leasing, koperasi syariah, pegadaian syariah dan berbagai bentuk bisnis lainnya. Hal ini bisa ditemukan dalam beberapa aspek model ekonomi, jual-beli online, multi level marketing (MLM), dan lain sebagainya. ${ }^{2}$

Loncatan dan respon terhadap kemajuan teknologi modern dan sains sudah mengakibatkan efek yang sangat signifikan bagi kehidupan manusia, khususnya efek atas perkembangan bisnis dan ekonomi, seperti pada tata cara berdagang yang lebih modern dengan e-commerce, sistem peminjaman dan pembayaran menggunakan kartu kredit, SMS banking, perdagangan internasional/ekspor-impor dengan media L/C, sampai pada instrumen pengendalian moneter, exchange rate, wakaf saham, jaminan fiducia (rahn tasjiliy) dalam pembiayaan, jaminan resi gudang, dan lain sebagainya. Hal ini bisa ditemukan dari maraknya kajian-kajian dan pandangan-pandangan mengenai ekonomi syariah. $^{3}$

Dalam rangka mengembangan ekonomi syariah dengan memajukan lembaga syariah, sehingga bisa bersaing sesuai dengan apa yang dibutuhkan oleh masyarakat modern, diperlukan gagasan-gagasan baru yang masih mengedepankan prinsip ekonomi syariah. Kecuali hal tersebut, ekonomi syariah tidak hanya dalam bentuk lembaga keuangan, akan tetapi juga meliputi beberapa cakupan dan beberapa aspek yang sangat luas, seperti dalam hal kebijakan ekonomi Negara, ekonomi makro (kebijakan fiskal, public finance, strategi mengatasi kemiskinan dan pengangguran, inflasi, kebijakan moneter), serta permasalahan ekonomi lainnya, seperti upah pegawai, dan sebagainya. ${ }^{4}$

Dalam praktik perekonomian yang berdasarkan syariah, yang dikenal dengan ekonomi syariah. Dimana dalam prinsip dasar ekonoi syariah sangat menjunjung tinggi nilai-nilai etik. Namun dalam praktiknya dilapangan, praktik perekonomian hari ini ditemui berbagai problematika yang tidak menjung tingggi nilai-nilai etik dalam prinsip

\footnotetext{
${ }^{1}$ Abd. Shomad, "Konsep Lembaga Jaminan di Lingkungan Bank Syariah”, Jurnal Yuridika, Vol. 23 No. 3 Tahun 2008, hal. 1.

2 Abdur Rohman, “Analisis Konsep Bisyaroh Pada Jamaher Network Dalam Perpektif Ekonomi Islam”, Jurnal Tribakti, Volume 27 Nomor 2 September 2016, hal. 330-331.

${ }^{3}$ Wawan Gunawan Abdul Wahid, "Posisi Ushul Fikih dalam Metodologi Ekonomi Islam”, Jurnal Muqtasid, Volume 5 Nomor 1 Juni 2014, hal. 2.

${ }^{4}$ Rial Fu'adi, Aminuddin Ihsan, Masjupri, Ismail Yahya, "Upaya Reformasi Mata Kuliah Ushul Fiqh Pada Prodi Muamalah Dalam Menghadapi Perkembangan Ekonomi Syariah”, Jurnal Kodifikasi: Jurnal Penelitian Islam, Volume 6 Nomor 1 Tahun 2012, hal. 2. Volume 31, Nomor 1, Januari 2020
} 
perekonomian. Adanya penipuan, manipulasi harga, monopoli harga, riba, dan masih banyak lagi. Hal ini tentu menjadi suatu masalah yang sangat besar untuk segera diselesaikan. Potensi-potensi kaburnya penerapan prinsip-prinsip ekonomi syariah tersebut merupakan suatu hal yang bersifat urgent untuk segera ditanggulangi. ${ }^{5}$

Dalam setiap aspek hukum yang terkait dengan kajian ekonomi syariah, maka keterlibatan ahli hukum Islam menjadi penting untuk berperan dalam hal: ${ }^{6}$ pertama, Berijtihad memberikan solusi terhadap permasalahan ekonomi yang muncul, baik pada skala makro maupun mikro. Kedua, Mendesain akad dan perjanjian syariah untuk kebutuhan produk bisnis diberbagai lembaga keuangan syariah. Ketiga, Menjamin serta mengawal semua produk perbankan dan produk keuangan syariah agar didistribusikan sesuai syariah.

Dalam rangka mengembangkan ekonomi syariah serta merespon kondisi perekonomian hari ini, ahli hukum Islam harus cermat dan kreatif dalam mengembangkan hukum Islam dengan menggunakan metode istimbath hukum yang relevan. Istihsan yang dikembangkan dan dicetuskan oleh Imam Hanafi yang mewakili kelompok rasionalis, tentu metode ini mempunyai implikasi yang sangat signifikan terhadap pengembangan hukum ekonomi syariah. Dikarenakan istihsan yang lebih mengedepankan rasionalitas dipandang mempunyai porsi yang sangat lebih dibandingakan dengan metode yang mengedepankan teks belaka.

\section{Metode Penelitian}

Dalam melakukan penelitian ini, peneliti menggunakan jenis penelitian studi pustaka (library reseach), yaitu penelitian yang dilaksanakan dengan melakukan kajian terhadap literatur, penelitian terdahulu, serta sumber-sumber lainnya yang terkait dengan penelitian ini. ${ }^{7}$ Dalam melakukan penelitiann ini, peneliti akan mengkaji literatur-literatur yang membahas tentang konsep istihsan dan ekonomi syariah. Sifat dalam penelitian ini ialah deskriptif analitik, yaitu peneliti berusaha mengaktualisasikan konsepsi mengenai istihsan yang kemudian diaktualisasikan terhadap pengembangan ekonomi syariah.

Data yang digunakan dalam penelitian ini adalah data primer, yaitu data yang diambil dari sebuah penelitian dengan menggunakan instrumen ${ }^{8}$ Data primer dalam penelitian ini adalah data-data yang diambil dari bahan-bahan bacaan, antara lain, dokumen resmi, buku-buku, laporan penelitian terdahulu, kitab-kitab ushul fiqh. Penulis penggunakan bahan hukum primer sebagai rujukan utama, bahan hukum primer ini diambil dari kitab-kitab ulama' yang membahas ushul fiqh, khususnya yang membahas tentang istihsan dan ekonomi syariah.

\section{Madzhab Ushul Imam Hanafi}

${ }^{5}$ Gahnsam Anand, Kukuh Leksono S. Aditya, Bagus Oktavian Abrianti, "Problematika Aplikasi Ekonomi Syariah Dalam Rezim Hukum Kepailitan”, Jurnal Bina Mulia Hukum, Volume 2, Nomor 1, September 2017, hal. 70 .

${ }^{6}$ Rial Fu'adi, Aminuddin Ihsan, Masjupri, Ismail Yahya, "Upaya Reformasi............., hal. 2-3. hal. 18 .

${ }^{7}$ Jonathan Sarwono, Metode Penelitian Kuantitatif dan Kualitatif, (Jogjakarta: Graha Ilmu, 2006),

${ }^{8}$ Sarwono, hal. 30-32. 
Madzhab ini dibangun berdasarkan pemikiran Imam Abu Hanifah (w. 150 H/767 M). Nama beliau ialah Nu'man Ibn Tsabit Ibn Zauta, yang selanjutnya popular dengan julukan Abu Hanifah. Baliau dilahirkan di Kufah pada tahun 80 H/699 M, dan meninggal pada tahun $150 \mathrm{H} / 767 \mathrm{M} .{ }^{9}$ Beliau adalah faqih yang lebih dominan dalam menggunakan ra'yu, atau lebih condong mengedepankan akal pada ijtihad-nya. ${ }^{10}$ Pemikirannya berpengaruh dan mengalami perkembangan di beberapa Negara Islam seperti di Irak, Syam serta beberapa Negara Islam lainnya, juga tersebut di Mesir dan daerah-daerah lainnya. ${ }^{11}$ Ketika masa kanak-kanak Abu Hanifah sudah gemar membaca dan menghafal Al-Qur'an, meskipun ia ikut berdagang di pasar bersama ayahnya (usahawan besar sebagai penjual kain sutra). ${ }^{12}$ Melihat kecerdasan Abu Hanifah. ${ }^{13}$ Abu Hanifah mempelajari berbagai keilmuan keagamaan yang dominan di Kufah yang merupakan kota pusat ilmu dan kebudayaan. Diantaranya term-term ilmu agama, dan selalu diadakan sebuah diskusi yang penuh dengan perdebatan tentang agidah, Hadits, dan Fiqh. Beliau lebih banyak menekuni dan mengarahkan pikirannya pada bidang pemikiran fiqh $^{14}$

Dalam belajar, Abu Hanifah belajar pada Hamad ibn Sulaiman (ulama terkenal di Kufah) selama delapan tahun, kemudian pada ulama-ulama Makkah dan Madinah. ${ }^{15}$ Juga pada Zaid ibn Ali, Ja'far As-Shadiq, Abdullah ibn Hasan dan para Tabi'in yang ahli dibidang fiqh. Ketika di Makkah pernah berdiskusi dengan Imam Auza'i. ${ }^{16}$ Ketika berusia empat puluh tahun gurunya Hamad ibn Abi Sulaiman wafat lalu beliau menggantikan kedudukan gurunya untuk mengajar ilmu agama. Disini Abu Hanifah mulai mencetuskan pendapat-pendapatnya yang sering mengakibatkan kontroversi dan mengembangkan teori dan metode istinbath hukum. Beliau tidak segan-segan mengeluarkan kritik-kritik tajam terhadap fatwa atau putusan hakim atau Qhadi yang bekerja pada pemerintah. Akibatnya beliau dipenjarakan sampai wafat. ${ }^{17}$ Karena ketegaran pikiran dan keleluasaan ilmunya, Abu Hanifah banyak mempunyai pengikut dan murid. Dari sini muncullah pemahaman fiqh dan metode penetapan hukum berdasarkan pemikiran dan pola istinbath Abu Hanifah. Pengaruhnya cukup besar, sehingga melahirkan mazhab tersendiri dalam bidang ushul fiqh, atau apa yang disebut dengan Ushul al-Mazhab al Hanafiyah. Tidak dipungkari bahwa peran murid-murid Abu Hanifah dalam hal pengembangan dan menyebarluaskan pemikirannya tidaklah kecil, karena melalui murid-muridnya ini pemikirannya tersebar.

Di antara murid-murid Imam Abu Hanifah yang terkenal ialah Imam Abu Yusuf dan Muhammad ibn al-Hasan al-Syaibani. Kedua orang murid beliau ini dalam menetapkan hukum dan memberi fatwa berpijak pada tata cara yang dilalui oleh Abu

${ }^{9}$ Hasan Abu Thalib. Tatbiq al-Syari'ah al-Islamiyah Fi al-bilat al-Arahiyah. (Kairo: Dar alNahdah al-Arabiyah, 2005), hal. 73.

10 Muhammad Abu Zahrah. Tarikh al-Mazahib al-Fiqhiyah. (Kairo: Matba' al-Madani, tt., hal.188.

${ }^{11}$ Abu Zahroh, hal. 188-200

${ }^{12}$ Hasbi ash-Shidqi. Pokok-pokok Pegangan Imam Imam Mazhab Dalam Membina Hukum Islam. Jihd II, (Jakarta; Bulan Bintang, 2001), hal. 198.

13 ash-Shidqi, hal. 199.

14 ash-Shidqi, hal.199-200.

15 ash-Shidqi, hal. 200.

${ }^{16}$ Mun'in A. Sirry. Sejarah Fiqh Islam (Surabaya: Risalah Gusti, 1995), hal. 83.

${ }^{17}$ Ash Shidqi, Pokok-pokok Pegangan ...., hal. 202. 
Hanifah. Imam Abu Yusuflah ${ }^{18}$ orang pertama yang menulis berbagai macam buku berdasarkan madzhab Hanafi serta menyebarluaskan ke berbagai daerah guna dipelajari, termasuk ushul fiqih. Demikian pula Muhammad ibn al-Hasan al-Syaibani banyak mengambil ilmu dari Abu Hanifah serta menyebarluaskan pemikiran Abu Hanifah melalui karya-karyanya. ${ }^{19}$ Meskipun Abu Hanifah sendiri tidak meninggalkan sebuah karyanya yang ditulis secara langsung.

Abu Zahrah, ${ }^{20}$ mengungkapkan bahwa penulisan dalam bidang ushul fiqh pertama kalinya ditulis oleh murid Abu Hanifah. ${ }^{21}$ Hal ini juga dikemukakan oleh Hasan Abu Thalib bahwa pemikiran dan dasar-dasar ushul fiqh Abu Hanifah dibukukan oleh muridnya. Menurut penuturan Imam Nadim sebagai dikutip oleh Hasbi Ash Shidiqi, ${ }^{22}$ bahwa Abu Yusuf dan Zuhar adalah dua orang murid yang sangat berjasa dalam merumuskan dan mengembangkan sebuah pemikiran Abu Hanifah serta madzhab ushul Imam Hanafi. Abu Yusuf sendiri banyak menghasilkan karya-karya yang didasarkan kepada mazhab Hanafi, seperti kitab al-Zakah, al-Siyain, al-Faraidl, al-Hudud, alKharraj dwi al-Jami' ${ }^{23}$

Selain mereka, Ibn al-hasan juga mengikuti cara istinbath yang sudah diprakarsai oleh Abu Yusuf berlandaskan pemikiran Abu Hanifah. Dalam kegiatan istinbath, madzhab Hanafi menempuh langkah-langkah sebagai berikut, pertama - berpegang kepada al-Kitab, kedua, as-Sunnah, kefiga, Qoul Sahabi, keempat, al-Ijma', kelima, alQiyas, keenam, al-Istihsan dan ketujuh, al- 'Urf. ${ }^{24} \mathrm{Abu}$ Hanifah seperti juga diikuti oleh pengikutnya lebih mendahulukan penggunaan al-Istihsan bila jelas kemaslahatannya atau mendahulukan al-Istihsan dan mengenyampingkan qiyas dikarenakan sebuah perkara khusus yang lebih penting (darurat). ${ }^{25}$ Begitu pula dengan penggunaan al-Sunnah sebagai hujjah, beliau sangat selektif, hanya berpegang kepada sunnah yang kuat dan dapat dipercaya (tsiqat). Oleh karenya mazhab Hanafi ini dikenal dengan mazhab yang cenderung lebih banyak berpijak pada ra'yu. Bahkan Abu Yusuf, melakukan ijtihad melampaui masanya, dengan memperkirakan hal-hal yang belum terjadi. ${ }^{26}$

Dari beberapa sumber ditemukan bahwa yang menjadi dasar istinbat (ushul alIstinbat) dan sistematika sumber dan metode istimbath hukum mazhab Hanafi, sebagai dijelaskan oleh Hasan Abu Thalib 27 meliputi: Al-Kitab (الكناب), As-Sunnah (السـنه), Al-

${ }^{18}$ Muhammad Ali al-Sayis. Tarikh al-Fiqh al-Islami. (Kairo: Maktabah wa Matba'ah Ali Sabih wa auladuh, tt), hal. 95.

19 al-Sayis.

${ }^{20}$ Muhammad Abu Zahrah. Ushul al-Fiqh. (Mesir: Dar al-Fikr al-Arabi, 2005), hal 21.

${ }^{21}$ Hasan Abu Thalib. Tatbiq al-Syari'ah al-Islamiyah. Fi al-Bilat al-Arahiyah, (Kairo: Dar alNahdah, Cet, III. 1990), hal.156.

${ }^{22}$ Ash Shidqi. Pokok-pokok Pegangan..., hal. 214.

23 Ash Shidqi, hal. 214-215.

${ }^{24}$ Dasar-dasar istinbath ini adalah berdasarkan penuturan Abu Hanifah sendiri diungkapkan oleh para murid beliau. Lihat Hasan Abu Thalib. Op. cit. hal. 158. bandingkan dengan Muhammad Ali al-Sayis. Nasyah al-Ijtihad wa atwaruh, (Kairo: Majma' a1-Bukus al-Islamiyah, 2000), hal. 94-95. Selanjutnya lihat pula dalam Sya'ban Muhammad lsmail, Al-Tasyri al-Islami Masadiruh wa Atwaruh, (Kairo: Maktabah alNahdah al-Misriyah, 2004), hal. 316.

${ }^{25}$ Hasan Abu Thalib. Tatbiq al-Syari'ah..., hal.158.

${ }^{26}$ Thalib, hal. 158-160.

27 Thalib, hal. 158.

Tribakti: Jurnal Pemikiran Keislaman

Volume 31, Nomor 1, Januari 2020 


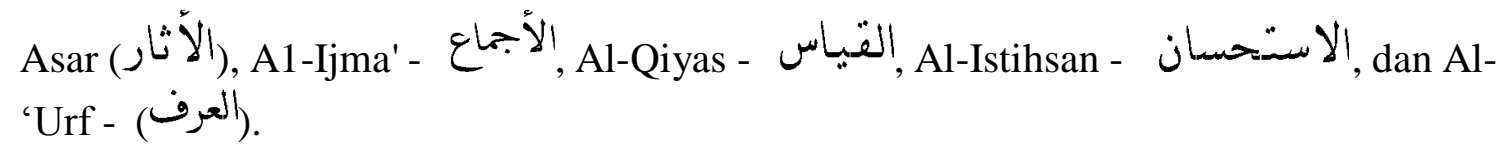

\section{Istihsan Sebagai Metode istimbath Imam Hanafi}

Dalam pandangan al-Sarakhsi (w. $483 \mathrm{H}),{ }^{28}$ secara etimologis (bahasa) istihsan berarti Berusaha mendapatkan yang terbaik untuk diikuti bagi sesuatu masalah yang diperhitungkan untuk dilaksanakan. Sementara itu, menurut Muhammad al-Said All Abdur Rabuh, ${ }^{29}$ istihsan dalam pengertian bahasa berarti mempertimbangkan bahwa suatu perkara itu ialah baik. Adapun istihsan, menurut pengertian istilah, sebagaimana disebutkan oleh Abu al-Hasan al-Karkhi, ${ }^{30}$ seorang ulama ushul dari madzhab Hanafi adalah sebagai berikut:

"Istihsan ialah berpindahnya seorang mujtahid dari hal penetapan hukum pada suatu masalah yang secara substansial serupa dengan apa yang lelah ditetapkan karma terdapatnya alasan yang lebih kuat yang menghendaki perpindahan tersebut”. Kemudian, al-Sarakhsi, ${ }^{31}$ menyebutkan bahwa“"Istihsan adalah mengesampingkan sebuah qiyas dan menggunakan yang lebih kuat daripadanya, dikarenakan adanya sebuah dalil yang menghendaki serta lebih sesuai untukmewujudkan kemaslahatan bagi umat manusia". Senada pula dengan al-Sarakhsi di atas, Abdul Wahab Khalaf ${ }^{32}$ menyebutkan pula, bahwa istihsan adalah: istihsan adalam perpindahan mujtahid dari aturan qiyas yang jelas menuju ketetuan qiyas yang samar (tersembunyi), atau dari ketentuan yang kullyy (umum) menuju ketentuan hukum yang sifatnya khusus, karena dalam pandanagan mujtahid dalil (alasan) yang lebih kuat yang menghendaki perpindahan yang dimaksud”. Sementara itu, menurut Imam al-Bazdawi, sebagaimana dikutip oleh Abdul Karim Zaidan ${ }^{33}$ memberikan pengertian terhadap istihsan: "istihsan adalah perpindahan dari seharusnya menggunakan qiyas kepada sebuah ketentuan qiyas lain yang lebih kuat dengan pengkhususan ketentuan qiyas dengan menggunakan dalil yang lebih kuat".

Sebetulnya, masih terdapat beberapa definisi lagi, tetapi dipandang cukup mengemukakan empat definisi seperti telah disebutkan di atas. Berdasarkan empat definisi di atas ternyata Istihsan berkisar pada tiga hal. Pertama, bahwa Istihsan ialah pengubahan atau penyimpangan penetapan dan penerapan hukum yang telah ditetapkan kepada ketentuan yang lain pada suatu masalah karena terdapatnya alasan kuat yang menghendaki perubahan tersebut. Pengertian seperti ini terlihat dalam definisi yang dikemukakan oleh Abu al-Hasan al-Karkhi. Kedua, bahwa yang dinamakan dengan istihsan merupakan sebuah perpindahan terhadap ketentuan qiyas yang masih samar (tersembunyi) dikarenakan adanya sebuah alasan kuat yang dikehendaki. Pemahaman

\footnotetext{
${ }^{28}$ Al-Sarakhsi. Ushul al-Sarakhsi. Juz II. (Kuwait: Dar al-Qalam, 2002), hal. 200.

${ }^{29}$ Muhammad al-Said Ali Abdul Rabuh. Buhus fi al-Adillah al-Mukhtalaf Fiha 'inda al-Usuliyin. (Mesir: Matba' al-Sa'adah, 2004), hal. 53.

${ }^{30}$ Muhammad Abu Zahrah. Ushul al-Fiqh, hal. 262.

${ }^{31}$ Al-Sarakhsi. Ushul al-Sarakhsi. hal. 79 .

32 Abdul Wahab Khalaf. 'Ilm Ushul al-Fiqh. (Kairo: Maktabah al-Da'wah al-Islamiyah, 2008), hal. 230 .

${ }^{33}$ Abdul Karim Zaidan. Al-Wajiz. Fi Ushul Fiqh. (Baghdad: al-Dar al-Arabiyah Littiba'ah, 2003),
} 
semacam ini dalam perspektif al-Sarakhsi, al-Bazdawi, dan Abdul Wahab Khalaf. Ketiga, meninggalkan atas ketentuan kully dan mengamalkan ketentuan yang lebih khusus sebagai pengecualian dari ketentuan kully, atau mengkhususkan qiyas karena adanya sebuah dalil yang lebih kuat.

Atas dasar inilah, bahwa sesungguhnya istihsan memiliki sebuah kaitan dengan penerapan dan pelaksanaan ketentuan syariat yang sudah jelas nash-nya, baik diambil dari nash secara langsung, ijma', maupun qiyas. Namun demikian, determinasi syariat yang telah jelas ini tidak bisa dirubah dan diberlakukan begitu saja ketika berhadapan dengan sebuah permasalahan yang mengharuskan mewujudkan sebuah kemaslahatan umat. Dengan kesimpulan bahwa istihsan pada dasarnya mengesampingkan ketentuan umum yang sudah jelas untuk berpindah pada sebuah ketentuan baru yang lebih khusus dengan alasan dan tujuan untuk merealisasikan sebuah kemaslahatan. Artinya, persoalan yang lebih khusus harusnya tercakup pada sebuah ketentuan yang sudah jelas, akan tetapi tidak mungkin untuk bisaditerapkan, maka harus ada sebuah terobosan dengan ketentuan khusus sebagai pengecualian dari sebuah ketentuan umum atau yang telah jelas.

Di kalangan madzhab, ternyata memang terdapat perbedaan dalam mengartikan istihsan ini. Umumnya di kalangan Ulama Hanafi, sebagaimana disebutkan oleh Abdul Wahab Khalaf, ${ }^{34}$ bahwa Imam al-Bazdawi dan Imam al-Nasafi mengartikan istihsan itu dengan pindah dari ketentuan qiyas kepada qiyas lain yang lebih kuat atau pengkhususan qiyas dengan suatu dalil yang lebih kuat. Artinya, substansi istihsan di kalangan Ulama Hanafi karena terjadinya perlawanan dalam penerapan ketentuan qiyas. Seharusnya sebuah masalah dalam penerapannya berpijak pada sebuah ketentuan qiyas yang telah baku dan sudah jelas, akan tetapi ada sebuah alasan yang lebih kuat serta lebih tepat. Maka ketentuan berpegang kepada sebuah alasan yang lebih kuat untuk didahulukan dari pada ketentuan qiyas yang sudah jelas.

Sementara ulama' dari kalangan madzhab Hanafi ${ }^{35}$ berbeda dengan ulama' madzhab Maliki dalam mendefinisikan istihsan. Bagi Ulama dari kalangan Maliki istihsan itu ialah mengamalkan serta memilih sebuah dalil yang lebih kuat dari dua dalil. Berpegang kepada salah satu dalil yang terkuat dari dua dalil ini, bisa jadi karena pengkhususan yang umum atau karena pengecualian dari qiyas. Kemudian dikalangan madzhab Imam Ahmad Ibn Hambal (Hanabilah) bahwa istihsan itu ialah penyimpangan dari sebuah ketentuan hukum yang seharusnya berlaku karena ada dalil syara' yang khusus. ${ }^{36}$

Dengan demikian dapat dipahami bahwa pada hakekatnya istihsan itu seperti tercermin dari sejumlah definisi yang telah disebutkan di atas dengan suatu ketentuan hukum yang seharusnya diberlakukan tetapi karena ada sesuatu alasan (kemaslahatan) yang menuntut penetapan khusus sehingga ketentuan yang sudah jelas tersebut tidak dapat diberlakukan. Hal ini bisa jadi karena tidak dapat menerapkan qiyas pada suatu masalah, atau sebagai pengecualian bagi ketentuan hukum yang juz' $i$ dari yang kulliy atau

\footnotetext{
${ }^{34}$ Abdul Wahab Khalaf. Masadir al-Tasyri al-Islami Fima La Nassa Fih, (Kuwait: Dar al-Qalam, 2007), hal. 69-70.

${ }^{35}$ Khalaf.

${ }^{36}$ Khalaf.
}

Tribakti: Jurnal Pemikiran Keislaman

Volume 31, Nomor 1, Januari 2020 
bisa jadi pengkhususan sebagian dari makna yang umum dengan sebuah ketentuan hukum yang lebih khusus.

Jika ditelusuri dasar sejarah dan perumusan istihsan sebagai metode istimbath hukum dan dalil hukum dimulai dari permasalahan qiyas. Qiyas sebagai salah satu metode istimbath hukumdan dalil hukum dalam beberapa aspek tidak dapat dipergunakan, karena salah satu dari rukun istihsan ('illat) tidak mencapai syarat. Dengan demikian, 'illat pada qiyas yang digunakan sebagai alasan penyamaan hukum tidak bisa diterapkan, dikarenakan tidak sebanding dalam 'illat-nya. Oleh karenanya, permasalahan tersebut harus dipecahkan dengan cara lain yang lebih dekat pada tujuan syara' (maqashid syari'ah).

Dasar perumusan dan pemikiran istihsan sepert itu, yang selanjutnya dijadikan sebuahh dalil dan metode istimbath hukum. Pada mulanya dimunculkan oleh Imam Abu Hanifah di kalangan para pengikutnya. Sebagaimana diungkapkan oleh Zaky al-Din Sya'ban, ${ }^{37}$ bahwa dikalangan mazhab Hanafi banyak persoalan-persoalan hukum fiqh yang ditetapkan berdasarkan istihsan. Salah satu contoh yang bisa diungkapkan yaitu mengenai bekas arir minuman burung liar (buas). Dalam hal ini, burung buas disamakan dengan hewan buas, dimana dagingnya tidak boleh dimakan dikarenakan mengandung najis. Maka secara otomatis ar liurnya juga mengandung najis. Maka, jika burung itu minung, maka sisia minumannya akan dinilai najis pula. Berdasarkan produk hukum yang dicetuskan dari qiyas, maka bekas minuman dari seekor burung buas yang disamakan dengan binatang buas, maka hukumnya sama, yaitu sisa minumannya menjadi najis. Namun demikian, bagi golongan ulama' yang menganut madzhab Hanafi, ${ }^{38}$ memberikan pandangan hukum bahwa bekas minuman burung buas tidak najis, disebabkan burung buas ketika minum menggunakan paruhnya, sehingga air yang diminum tidak mengenai air liurnya. Hal demikian tentu berbeda dengan binatang buas yang minum menggunakan mulutnya, sehingga air mengenai air liurnya yang najis.

Hasbi Ash-Shidqi, ${ }^{39}$ mengungkapkan bahwa munculnya istihsan disebabkan terdapat sebuah persoalan hukum Islam yang berlawanan dengan sebuah kaidah hukum yang sudah biasa digunakan lantaran sebuah sebab yang mewajibkan meninggalkan dan mengesampingkan sebuah kaidah lama. Disebabkan dengan meninggalkan kaidah yang sudah lazim dipergunakan justru akan lebih bisa mewujudkan tujuan-tujuan syariat (maqashid syari'ah). Penggunaan metode istihsan dalam ijtihad ini dalam perpektif Hasbi hanya bisa dilakukan pada sebuah elemen masalah juz'iyyah dan bukan pada elemen masalah kulliyah.

Pasca penggunaan istihsan sebagai alasan penentuan hukum Islam, maka penggunaan istihsan tidak saja pada kalangan madzhab Hanafi saja, akan tetapi pada awal perumusan istihsan berangkat dari sebuah perlawanan dua dalil, sehingga jalan keluarnya adalah dengan memilih sebuah dalil yang paling kuat dan paling bisa membawa pada kemanfaatan, ataupun juga penerapan atas pengecualian dari penerapan dalil kully.

\footnotetext{
${ }^{37}$ Zaky al-Din Sya'ban. Ushul Fiqh al-Islami, (Mesir: Matba' Dar al-Ta'lif, 2009), hal. 154.

38 Abu Zahrah. Ushul Fiqh, hal. 266.

${ }^{39}$ Hasbi Ash Shidqi. Pokok-pokok Pegangan ..., hal. 163.
} 
Pengecualian dari dalil kully disini dalam pandangan Syatibi, ${ }^{40}$ berpegang pada sebuah kemaslahatan juz'I ketika ada sebuah pertentangan dengan dalil yang kully. Dalam kondisi lainnya, kelompok madzhab Maliki, mengatakan bahwa istihsan termasuk metode yang memprioritaskan maslahah daripada qiyas. Artinya, jika terjadi sebuah pertentangan antara maslahah dengan qiyas, maka maslahah-lah yang harus didahulukan.

Selanjutnya dari kalangan madzhab Hambali merumuskan istihsan sebenarnya didasarkan pada tiga pemikiran. ${ }^{41}$ Pertama, penyimpangan atas suatu ketentuan hukum yang semestinya diberlakukan karena adanya dalil dari nash yang khusus. Kedua, sesuatu yang dipandang baik berdasarkan pertimbangan mujtahid. Ketiga, adanya sebuah dalil yang dalam pandangan mujtahid_itidak bisa didebatkan._Atas dasar ini, dapat dilihat bahwa masing-masing mazhab ushul mempunyai dasar pemikiran sendiri-sendiri dalam perumusan istihsan sebagai dalil dalam istinbath hukum.

\section{Ekonomi Syariah: Sebuah Tinjauan}

Pengertian Ekonomi islam adalah sebuah sistem ekonomi yang di bangun berlandaskan ajaran islam, karena aktivitas perekonomian dalam islam bagian yang tidak bisa dipisahkan dari ajaran islam, sebagai sistem kehidupan, yang berlandaskan pada nash, dimana islam menyediakan seperangkat aturan yang sempurna demi kemaslahatan umat manusia. ${ }^{42}$ Selain itu ekonomi Islam juga mengajarkan prilaku seorang yang di tutun oleh ajaran Islam, bagaimana cara memandang serta menganalisis setiap masalah dalam berekonomi,dan bagaiman menerapan prinsip-prinsip ekonomi islam atau nilai ekonomi islam yang harus di dijadikan pedoman dalam mencapai tujuan. Guna menjelaskan pengertian dari ekonomi islam secara makro maka ada pendapat beberapa ahli pemikir ekonomi islam sebagai berikut:

Muhamad abdul Mannan dalam "Islamic Ekonomics: Theory and Practice" "Islamic economics is a social science which studies the economics problems of a people imbuea with the values of islam" (Ekonomi Islam adalah ilmu sosial yang mempelajari masalah-masalah ekonomi orang yang di jiwai dengan nilai nilai Islam). ${ }^{43}$ Muhammad Nejatulloh al shiddiqi dalam Muslim Economic Thinking: A Survey Of Contemporery literature. "Islamics economics is the muslim thinker's respon to the economic challenges of their time, in this edeavour they were aided by the qur'an and the Sunnah as well as by reason and experience(Ilmu ekonomi islam adalah respon pemikir Muslim terhadap tantangan ekonomi pada masa tertentu dalam usaha keras ini mereka di bantu oleh alquran dan sunnah ,akal (ijtihad) dan pengalaman. "44 Dalam buku berjudul The Future of Economics an Islamic perpektif disebutkan: "Islamic economics was defined as that branch of knowledge wich helps relie human well-being through an allocation and

${ }^{40}$ Al-Syatibi. Al-Muwafaqat fi Ushud al-Syari'ah. Jilid IV, (Beirut: Dar al-Ma'rifah, 2009), hal. 206-208.

${ }^{41}$ Abdul Wahab Khalaf. Masadir al-Tasyri al-Islami.... , hal. 70

42 Aan Anshori, "Digitalisasi Ekonomi Syariah", Jurnal Islamiconomic: Jurnal Ekonomi Keuangan dan Bisnis Islam, Volume 7 Nomor 1 2016, hal. 4-6.

${ }^{43}$ Muhammad Abdul Manan, Islamic Economic, Theory and Practice, (Cambridge: Hourder and Stounghton, tt.), hal. 18 .

${ }^{44}$ Muhammad Najetullah Siddiqi, Rule of the state in the Ekonomic, In Islamic Prespecktive, (UK. The Islamic Foundation, 2009), hal. 69.

Tribakti: Jurnal Pemikiran Keislaman

Volume 31, Nomor 1, Januari 2020 
distribution of scarce resources that is in conformity with Islamic teaching without unduly curbing individual freedom or creating continued macro economic and ecological imbalances"(Ekonomi islam didefinisikan sebagai cabang ilmu yang membantu mensejahterakan kesejahterakan manusia islam tanpa terlalu mengekang kebebasan indhividu atau menciptakan ketidakseimbangan ekonomi makro dan ekologi yang berkelanjutan. ${ }^{45}$

Dari berbagai pengertian mengenai ekonomi syariah diatas penulis menyimpulkan bahwa ekonomi syariah memadukan konsep nilai dan keilmuan. Korelasi antara ilmu dan nilai ini akan mampu menyajikan ekonomi syariah sebagai sebuah konsep yang integral dalam rangka membangun keutuhan hidup pada masyarakat. Ekonomi syariah sebagai keilmuan yang bisa dicerna dengan metode ilmu pengetahuan, sedangkan ekonomi syariah sebagai nilai membuat ekonomi syariah bisa relevan dengan kondisi dan fitrah manusia, serta memberikan pengaruh serta menyambungkan peran terhadap keberlangsungan kehidupan manusia.

\section{Istihsan Sebagai Cara Mengembangkan Ekonomi Syariah}

Sebagaimana diketahui bersama bahwa tujuan pemberlakuan syariah ialah guna mewujudkan maslahah dan menolak kerusakan, baik di dunia mapun di akhirat. hal ini bermakna bahwa setiap aspek dalam ajaran Islam harus tertuju pada terwujudnya tujuan tersebut, tidak terkecuali pada bisa ekonomi. Oleh karena itu, ekonomi syariah harus berperan menjadi sebuah solusi bagi problematika perekonomian yang terjadi hari ini. Konsekuensi logisnya ialah, bahwa guna menciptakan sebuah bangunan ekonomi syariah tidak bisa dilepaskan dari teori kebaikan dan maslahah yang merupakan esensi dari metode istihsan. ${ }^{46}$ Ekonomi syariah yang cukup lama mengalami stagnasi pengembangan dan tergeser dengan ekonomi konvensional tentu memiliki peluang besar untuk dijadikan lahan ijtihadi. Artinya, kerja keras (ijtihad) dari para pakar hukum Islam diperlukan guna mencari terobosan-terobosan baru dalam metode istimbath hukum. Untuk selanjutanya terobosan ideal tersebut diderivasikan menjadi sebuah teori ekonomi syariah yang kemudian bisa dijadikan kaidah pada tataran praktik.

Perbedaan yang cukup signifikan antara konsep ekonomi syariah dan ekonomi konvensional terletak pada wilayah nilai etik. Diantara perilaku ekonomi yang memiliki nilai etik adalah, etika pada perilaku konsumen, etika keadilan distributif, dan etika yang dikaitkan dengan peran penguasa. Variabel etika dalam ekonomi syariah ini tampaknya mempunyai posisi yang sangat urgen dalam proses ijtihad dalam rangka mengembangkan ekonomi syariah. Dalam mengembangkan ekonomi syariah, metode yang menekankan pada wawasan etis dengan harapan bisa memenuhi maksud diatas, istihsan sebagai salah satu metode istimbath hukum Imam Hanafi, perlu dinaikkan derajat dan posisinya guna dijadikan sebuah metode sentral dalam rangka pengembangan ekonomi syariah. Ekonomi syariah yang dalam banyak hal merupakan reinkarnasi dari fiqh mu'amalah sudah selayaknya mengembalikan kelenturan dan elastisitas hukum Islam (fiqh) dengan

${ }^{45}$ Siddiqi.

${ }^{46}$ Moh. Syarifudin, "Maslahah Sebagai Alternatif Istimbath Hukum dalam Ekonomi Syariah", Jurnal Lentera, Volume 17 Nomor 1, Maret 2018, hal. 55-56.

Tribakti: Jurnal Pemikiran Keislaman Volume 31, Nomor 1, Januari 2020 
menjadikan istihsan yang mempunyai esensi kebaikan dan maslahah sebagai the ultimate goal dalam proses tersebut.

Aturan-aturan dalam syariah memiliki keterkaitan dengan berbagai dimensi pada aspek kehidupan manusia. Aspek-aspek pada bidang ekonomi hanya sebagai salah satu dari serangkaian kehidupan manusia. Esensi dari ajaran istihsan semestinya memiliki implikasi pada tindakan ekonomi disetiap individu muslim. Selain hal tersebut, para pelaku ekonomi muslim tidak bisa melupakan implikasi-implikasi saat melakukan analisis ekonomi pada framework agama Islam. Susunan yang mengutraikan dan implikasi dari metode istihsan dalam pengembangan ekonomi syariah ini merupakan sebuah tantangan dan juga tugas yang amat berat, yang harus selalu diusahakan oleh para pelaku ekonomi muslim. Uraian dibawah ini akan berusaha menderivikasikan teori metode istihsan ke dalam teori ekonomi syariah.

1. Istihsan dalam ekonomi syariah

Kebaikan dan mafsadat tentu sudah diketahui secara akal, sedangkan pengettahuan yang berkaitan dengan kedua hal tersebut termasuk pokok bahasan syariah, yaitu mewujudkan maslahah/kebaikan dan menolak mafsadat/kerusakan. ${ }^{47}$ Dalam ketentuan mengenai kegiatan ekonomi, konsep kebaikan yang diredupsi dari istihsan merupakan sebuah ilustrasi dasar tentang perwujudan nilai-nilai ajaran Islam di setiap aspek kehidupan manusia. Konsep ekonomi syariah yang sebenarnya bukan hal yang baru dalam dunia Islam, dahulu para pakar ekonomi syariah klasik telah memikirkan mengenai hal ini. Pemikiran mengenai ekonomi syariah muncul sebagai salah satu tradisi intelektual muslim, walaupun masih sangat sederhana sesuai dengan konteks zaman dan tantangan kehdiupan yang berkembang pada saat itu. Selama ini, kajian dan pemikiran ekonomi syariah tidak bisa dilepaskan dari pemikiran hukum Islam (fiqh). Dalam pemikiran hukum Islam tidak bisa dilepaskan dengan prinsip maslahah, kebaikan, dan keseimbangan. Dengan demikian, istihsan sebagai metode yang merrealisasikan prinsip tersebut tentu mempunyai keselarasan khusus dalam keberlangsungan dan pengembangan hukum ekonomi syariah.

Upaya ini sebagai langkah internalisasi nilai-nilai ekonomi syariah dalam seluruh aspek perekonomian bangsa. Penanaman nilai-nilai ekonomi syariah ini akan mempunyai pengaruh terhadap perilaku economic agent. Misalnya, ketika seseorang mengetahui bahwa kejujuran mempunyai implikasi nilai-nilai ibadah kepada Allah, termasuk perilaku yang bertentangan dengan syariah, seperti khianat, korupsi, serta mengurangi takaran dan timbangan. ${ }^{48}$ Internalisasi nilai-nilai syariah dalam ekonomi syariah di Indonesia sebagai upaya pengembangan karakter bangsa dan keilmuan, apalagi orang Indonesia mayoritas memeluk agama Islam. ${ }^{49}$ hal ini bertujuan untuk mengembangkan potensi-potensi yang dimiliki orang Islam dengan membawa prinsip dasar ekonomi Islam. ${ }^{50}$

${ }^{47}$ Muhammad Izzu al-Din Ibn Abi Salam, Qawa 'id al-Ahkam fi Masalih alAnam, (Beirut: Dar al-Kutub al-Ilmiyyah, 1999), hal. 12.

${ }^{48}$ Bambang Iswanto, "Peran Bank Indonesia, Dewan Syariah Nasional, Badan Wakaf Indonesia dan Baznas Dalam Pengembangan Hukum Ekonomi Islam di Indonesia", Jurnal Iqtishadia, Volume 9, Nomor 2, 2016, hal. 425.

${ }^{49}$ Akhmad Mujahidin, "Peranan Kearifan Lokal (Local Wisdom) Dalam Pengembangan Ekonomi dan Perbankan Syariah di Indonesia”, Jurnal Ilmiah Syari'ah, Volume 15, Nomor 2, Juli-Desember 2016, hal. 157.

${ }^{50}$ Ugin Lugina, "Pengembangan Ekonomi Pondok Pesantren Di Jawa Barat", Risalah: Jurnal Pendidikan dan Studi Islam, Volume 4, Nomor 1, 2018, hal. 62.

Tribakti: Jurnal Pemikiran Keislaman

Volume 31, Nomor 1, Januari 2020 
2. Istihsan dalam produksi barang

Produksi barang memiliki makna yang sama dengan eksplorasi, yaitu pergerakan sumber daya alam melalui ilmu pengetahuan yang dikembanngkan oleh pengetahuan manusia. Salah satu contoh yang diajarkan oleh al-Qur'an adalah terkait tanah yang memiliki fungsi sebagai penyerapan air hujan dan kemudian tumbuh tanaman yang beragam. Tanaman tersebut kemudian bisa dimanfaatkan manusia sebagai produksi alam, dari tanaman itulah hewan bisa mengkonsumsinya dan selanjutnya hewannya bisa dimanfaatkan (diproduksi) oleh manusia dalam bermacam bentuk dan juga bisa dimanfaatkan dagingnya, susunya, dan lainnya. Penjelasan ini mengisyaratkan agar manusia memikirkan siklus kehidupan. Artinya, bahwa ketika produksi tidak memperdulikan faktor keseimbangan alam, maka siklus alam tidak bisa berjalan secara normal, yang pada akhirnya akan menimbulkan satu dampak yang sangan negatif. Korelari antara istihsan dan ekonomi syariah tidak menyetujui adanya ketimpangan, kelangkaan, kenaikan harga yang memberatkan, pemutusan kerja dan lain sebagainya. ${ }^{51}$ Dalam posisi inilah, istihsan memmpunyai posisi yang sangat tepat dalam rangka mengkritik serta mengembangkan prinsip-prinsip ekonomi syariah. Agar proses produksi barang sejalan dengan prinsip-prinsip utama yang dibawa oleh istihsan, yaitu mengambil sebuah manfaat yang lebih banyak, khususnya terciptanya manfaat secara umum.

3. Istihsan dalam konsumsi barang

Islam sebagai agama yang memberikan kelengkapan dalam ajaran dan telah memberikan panduan hidup manusia telah memberikan rambu-rambu dalam konsumsi. Istihsan dengan segala esensi kebaikan, keseimbangan, dan maslahah-nya telah memberikan penilaian terhadap praktik konsumerisme yang sangat bertentangan dengan esensi ajaran Islam. hal ini bisa diambil benang merah bahwa produksi yang berlebihan akan merusak siklus alam. Semakin alam dieksploitasi, alam akan mengalami kerusakan, yang pada endingnya akan merebak pada kesenjangan sosial. Pada posisi yang demikian, kuncinya ialah bagaimana kita bisa menata anggaran pendapatan serta belanja rumah tangga. Pengaturan belanja yang baik mewujudkan setengah usaha serta diangggap sebagian dari mata pencaharian. Karrena dalam ajaran Islam mengisyaratkan umatnya agar bekerja yang baik dan mengkonsumsi sesuatu dengan cara yang baik juga. Dengan model pemikiran terhadap konsumsi barang dengan menggunakan pendekatan istihsan, tujuannya agar konsumsi barang bisa seimbang dengan penghasilan, walhasil bisa menciptakan sebuah keseimbangan dalam kehidupan manusia.

4. Istihsan dalam akad

Salah satu kegiatan dalam perekonomian adalah akad, akad merupakan awal dari sebuah aktivitas perekonomian. Dalam kondisi hari ini, akad yang diajarkan oleh agama harus bertemu dalam satu majlis untuk melakukan kesepakatan akad dipandang sesuatu yang sangat ketinggalan. Apalagi jika disandingkan dengan aktivitas perekonomian hari ini, seperti jual beli online. Dimana dalam jual beli secara online antara pembeli dan penjual tidak bertemu untuk berakad. Istihsan yang mengakomodir prinsip kebaikan, kerelaan, dan unsur saling percaya untuk tidak melakukan kebohongan akad. Meodel semacam ini tentu membuat ekonomi syariah bisa merespon fenomena perokonomian hari ini, dengan ini istihsan bisa memberikan peluang terhadap pengembangan ekonomi syariah dan juga sebagai kritik atas hukum-hukum ekonomi Islam klasik.

5. Istihsan dalam distribusi barang

Distribusi difahami sebagai distribusi hakmilik secara pribadi dan sosial. Dalam ajaran agama Islam, setiap individu memiliki fungsi dan perannya masing-masing, sebagai individu

${ }^{51}$ Lugina,

Tribakti: Jurnal Pemikiran Keislaman Volume 31, Nomor 1, Januari 2020 
wajib baginya mengenai distribusi haarta yang ada padanya. Sebagai penjual juga dituntut untuk mendistribusikan dagangannya sesuai dengan tuntunan dan ajaran agama Islam. Sebagai manusia sosial wajib atasnya menjaga aset sosial dengan tujuan menguatkan hubungan kemanusiaan serta terciptanya keseimbangan alam supaya tidak dieksploitasi secar berlebihan. Sebagai Negara dan pemerintah juga harus menciptakan sebuah peraturan yang tidak memberikan peluang monopoli kelas sosial antara satu dengan lainnya, sehingga keseimbangan pasar modal dan keseimbangan non-ekonomi bisa terwujud. Dalam kondisi yang demikianlah, istihsan yang membawa prinsip kebaikan, keseimbangan, dan maslahah hadir sebagai metodologi baru dalam bidang distribusi barang. Sehingga kehadiran ekonomi syariah yang berangkat dari pemikiran istihsan mampu merespon dan menjadi sebuah kritik atas pelanggaran-penggaran distribusi barang dalam praktik perekonomian Negara.

\section{Kesimpulan}

Istihsan sebagai metode ijtihad yang dikembangkan oleh Imam Hanafi mempunyai inti dalam penggalian hukum dengan berpindah pada suatu hukum dengan pertimbangan, alasan, dan maslahah yang lebih kuat. Dalam ijtihad menggunakan istihsan sebagai upaya mengembangkan ekonomi syariah, lebih mengambil sebuah alternatif dan terobosan baru yang lebih kuat dan mengandung maslahah lebih kuat. Ekonomi syariah mempunyai prinsi-prinsip dasar yang berbeda dengan ekonomi konvensional. Prinsip yang dikembangkan oleh ekonomi syariah maupun agama Islam adalah prinsip, kebaikan, kejujuran, maslahah, dan tidak menimbulkan mafsadat (kerusakan). Dalam upaya mengembangkan ekonomi syariah, prinsip-prinsip ini yang harus dikembangkan secara proporsional, dalam rangka mengangkat ekonomi syariah dalam hal menanggulangi unsur-unsur kejahatan dalam kegiatan ekonomi, seperti kebohongan, monopoli harga, penimbunan barang, dan lain sebagainya. Dengan demikian, ekonomi syariah memiliki corak dan nilai tersendiri dalam rangka mewujudkan praktik ekonomi yang jujur, bermartabat, serta membawa maslahah. Istihsan sebagai satu dari beberapa metode istimbath hukum yang dikembangkan oleh Imam Hanafi yang membawa misi untuk mewujudkan unsur kebaikan, kejujuran, kerelaan, serta membawa maslahah tentu memiliki urgensi dan peluang besar dalam rangka mengembangkan ekonomi syariah untuk bisa merespon perkembangan perilaku ekonomi hari ini. Doktrin yang ditimpakan terhadap agama Islam yang selama jadul dan kuno, bisa terjawab dan dibuktikan dengan metode istihsan, agar ekonomi syariah bisa selalu eksis dan bisa bersaing dengan ekonomi konvensional. 


\section{Daftar Pustaka}

Aan Anshori, "Digitalisasi Ekonomi Syariah", Jurnal Islamiconomic: Jurnal Ekonomi Keuangan dan Bisnis Islam, Volume 7 Nomor 12016.

Al-Sarakhsi, Ushul al-Sarakhsi, Juz II, Kuwait: Dar al-Qalam, 2002.

Al-Sayis, Muhammad Ali, Nasyas al-Ijtihad wa Atwaruh, Kairo: Majma' al-Bukus alIslamiyah, 2000.

, Tarikh al-Fiqh al-Islami, Kairo: Maktabah wa Matba'ah Ali Sabih wa Auladuh, tt.

Al-Syatibi, Al-Muwafaqat fi Ushul al-Syariah, Jilid IV, Beirut: Dar al-Ma'rifah, 2009.

Anand, Gahnsan, Kukuh Leksono S. Aditya, Bagus Oktavian Abrianti,"Problematika Aplikasi Ekonomi Syariah Dalam Rezim Hukum Kepailitan”, Jurnal Bina Mulia Hukum, Volume 2,Nomor 1, September 2017.

Ash Shidqi, Hasbi, Pokok-pokok Pegangan Imam-imam Mazhab Dalam Membina Hukum Islam, Jilid II, Jakarta: Bulan Bintang, 2001.

Fu'adi, Rial, dkk., "Upaya Reformasi Mata Kuliah Ushul Fiqh Pada Prodi Muamalah Dalam Menghadapi Perkembangan Ekonomi Syariah", Jurnal Kodifikasi: Jurnal Penelitian Islam, Volume 6 Nomor 1 Tahun 2012.

Ismail, Sya'ban Muhammad, Al-Tasyri' al-Islami Masadiruh wa Atwaruh, Kairo: Maktabah al-Nahdah al-Misriyah, 2004.

Iswanto, Bambang,"Peran Bank Indonesia, Dewan Syariah Nasional, Badan Wakaf Indonesia dan Baznas Dalam Pengembangan Hukum Ekonomi Islam di Indonesia”, Jurnal Iqtishadia,Volume 9, Nomor 2, 2016. 2007.

Masadir al-Tasyri' al-Islami Fima La Nassa Fih, Kuwait: Dar al-Qalam,

Khalaf, Abdul Wahab, 'Ilm Ushul al-Fiqh, Kairo: Maktabah al-Da'wah al-Islamiyah, 2008.

Lugina, Ugin,"Pengembangan Ekonomi Pondok Pesantren Di jawa Barat", Risalah: Jurnal Pendidikan dan Studi Islam, Volume 4, Nomor 1, 2018.

Manan, Muhammad Abdul, Islamic Ekonomic, Theory and Practice, Cambridge: Hourder and Stounghton, tt.

Mujahidin, Akhad, "Peranan Kearifan Lokal (Local Wisdom) Dalam Pengembangan Ekonomi dan Perbankan syariah di Indonesia", Jurnal Ilmiah Syari'ah, Volume 15, Nomor 2, Juli-Desember 2016.

Rabuh, Muhammad al-Said Ali Abdul, Buhus fi al-Adilah al-Mukhhtalaf Fiha 'Inda alUshuliyin, Mesir: Matba' al-Sa'adah, 2004. 
Rohman, A. Analisis Konsep Bisyarah Pada Jamaher Network dalam Perspektif Ekonomi Islam. Jurnal Pemikiran Keislaman, 27(2), 2016, 329 347.

Salam, Muhammad Izzu al-Din Ibn Abi, Qowa'id al-Ahkam fi Masalih al-Anam, Beirut: Dar al-Kutub al-Ilmiyah, 1999.

Sarwono, Jonathan, Metode Penelitian Kuantitatif dan Kualitatif, Jogjakarta: Graha Ilmu, 2006.

Siddiqi, Muhammad Najetullah, Rule of the state in the Ekonomic, In Islamic Prespecktive, (UK. The Islamic Foundation, 2009.

Shomad, Abd., "Konsep Lembaga Jaminan di Lingkungan Bank Syariah, Jurnal Yuridika, Vol. 23 No. 3, 2008.

Sirry, Mun'im A., Sejarah Fiqh Islam, Surabaya: Risalah Gusti, 1995.

Sya'ban, Zaky al-Din, Ushul Fiqh al-Islami, Mesir: Matba'ah al-Ta'lif, 2009.

Syarifudin, Moh., "Maslahah Sebagai Alternatif Istimbath Hukum dalam Ekonomi Syariah”, Jurnal Lentera, Volume 17 Nomor 1, Maret 2018.

Thalib, Hasan Abu, Tatbiq al-Syari'ah al-Islamiyah Fi al-bilat al-Arahiyah, Kairo: Dar al- Nahdah al-Arabiyah, 2005.

Wahid, Wawan Gunawan Abdul, "Posisi Ushul Fikih dalam Metodologi Ekonomi Islam”, Jurnal Muqtasid, Volume 5 Nomor 1 Juni 2014.

Zahrah, Muhammad Abu, Tarikh al-Mazahib al-Fiqhiyah, Kairo: Matba' al-Madani, tt. , Ushul al-Fiqh, Mesir: Dar al-Fikr al-Arabi, 2005.

Zaidan, Abdul Karim, Al-Wajiz al-Tasyri' Fi Ushul Fiqh, Baghdad: al-Dar al-Arabiyah Littiba'ah, 2003. 
